\title{
Salmonella O9 による腸炎後に発症したアレルギー性紫斑病の兄妹例
}

\author{
県立広島病院小児科 \\ 坂野堯 松原啓太
}

(平成 15 年 5 月 2 日受付)

(平成 15 年 7 月 22 日受理)

Key words : Salmonella, Allergic purpura

アレルギー性紫斑病は, 日常診療上よく経験す る疾患である，その病態は全身の細血管の血管炎 であり, 病理組織では血管周囲の多核白血球を中 心とする炎症細胞浸潤がみられ，血管壁に IgA やフィブリンの沈着がみられる. 本症の 3 主徵で ある皮瘖症状, 関節症状, 消化器症状に加えて, 腎炎や神経系の合併症がよく知られている. 原因 は, 細菌, ウイルス, マイコプラズマなど感染症 に関連した報告, また, 牛乳, 卵, 魚肉などの食 物, 抗生剂などの薬剤に関連した報告がみられる。 その他, 予防接種, 昆虫刺傷, 寒冷刺激, 悪性腫 瘍によることも報告されているが, 発症機序に関 してはほとんど解明されていない。サルモネラ感 染との関連を示唆した報告はきわめてまれであ る ${ }^{122)}$ 。我々は, Salmonella O9 による腸炎後にアレ ルギー性紫斑病に罹患した兄妹例を経験したので 報告する。

\section{症例}

症例 $1: 4$ 歳 4 力月, 女览.

主訴: 腹痛, 膝関節痛, 紫斑.

現病歴：1997 年 9 月 7 日, 38〜 $39^{\circ} \mathrm{C}$ の発熱, 下 痢で発症し, 近医で加療したが改善なく9月 11 日から 16 日まで市内の救急病院へ入院となった。

ホスホマイシンなどで加療され, 以後は経過良 好にて退院した. 便培養では, Salmonella O9 が検 出された. 10 月 7 日から両側の膝関節痛, 腹痛が 出現し, 近医で治療を受けていたが, 10 月 15 日に

別刷請求先：( ( 734-8530)広島市南区宇品神田 $1 丁$ 目 $5-54$ 県立広島病院小巟科坂野堯
Table 1 Laboratory findings of patient 1

\begin{tabular}{lc}
\hline WBC & $8,600 / \mu \mathrm{l}$ \\
RBC & $396 \times 10^{4} / \mu \mathrm{l}$ \\
$\mathrm{Hb}$ & $12.2 \mathrm{~g} / \mathrm{dl}$ \\
$\mathrm{Ht}$ & $36.8 \%$ \\
Platelet & $39.6 \times 10^{4} / \mu \mathrm{l}$ \\
Total protein & $6.6 \mathrm{~g} / \mathrm{dl}$ \\
Albumin & $4.1 \mathrm{~g} / \mathrm{dl}$ \\
GOT & $23 \mathrm{mU} / \mathrm{ml}$ \\
GPT & $8 \mathrm{mU} / \mathrm{ml}$ \\
LDH & $368 \mathrm{mU} / \mathrm{ml}$ \\
BUN & $4.3 \mathrm{mg} / \mathrm{dl}$ \\
Cr & $0.3 \mathrm{mg} / \mathrm{dl}$ \\
Electrolytes & $n o r m a l$ \\
Amylase & $132 \mathrm{mU} / \mathrm{ml}$ \\
CRP & $0.4 \mathrm{mg} / \mathrm{dl}>$ \\
ASO & $114 \mathrm{IU} / \mathrm{ml}$ \\
IgG & $1,268 \mathrm{mg} / \mathrm{dl}$ \\
IgA & $242 \mathrm{mg} / \mathrm{dl}$ \\
IgM & $105 \mathrm{mg} / \mathrm{dl}$ \\
CH50 & $38.3 \mathrm{U} / \mathrm{ml}$ \\
C3 & $115 \mathrm{mg} / \mathrm{dl}$ \\
C4 & $35 \mathrm{mg} / \mathrm{dl}$ \\
Factor XII & $70 \sim 90 \%$ \\
\hline &
\end{tabular}

下肢の紫斑がみられたためアレルギー性紫斑病と 診断され, 当科紹介入院となった. サルモネラ腸 炎以後, アレルギー性紫斑病発症の誘因となる感 染などの既往はなし. サルモネラ腸炎の原因は生 卵で，父母兄の家族全員が罹患していた。

現症および経過：入院時, 理学的所見では, 下 肢の紫斑が散在し両側の膝関節の腫脹がみられた が，その他に異常所見をみなかった。 入院時の血 
Fig. 1 Clinical course of patient 1.

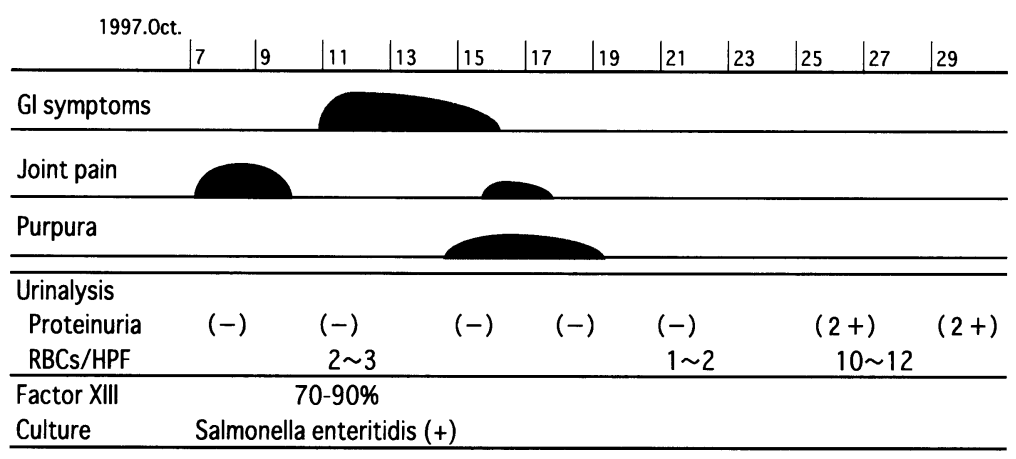

Table 2 Laboratory findings of patient 2

\begin{tabular}{lc|lc}
\hline WBC & $12,400 / \mu \mathrm{l}$ & IgG & $629 \mathrm{mg} / \mathrm{dl}$ \\
$\mathrm{RBC}$ & $410 \times 10^{4} / \mu \mathrm{l}$ & $\mathrm{IgA}$ & $299 \mathrm{mg} / \mathrm{dl}$ \\
$\mathrm{Hb}$ & $11.2 \mathrm{~g} / \mathrm{dl}$ & $\mathrm{IgM}$ & $183 \mathrm{mg} / \mathrm{dl}$ \\
$\mathrm{Ht}$ & $34.4 \%$ & $\mathrm{IgE}$ & $290 \mathrm{U} / \mathrm{ml}$ \\
Platelet & $30.3 \times 10^{4} / \mu \mathrm{l}$ & $\mathrm{CH} 50$ & $37.7 \mathrm{U} / \mathrm{ml}$ \\
Total protein & $6.3 \mathrm{~g} / \mathrm{dl}$ & $\mathrm{C} 3$ & $102 \mathrm{mg} / \mathrm{dl}$ \\
Albumin & $5.0 \mathrm{~g} / \mathrm{dl}$ & C4 & $23 \mathrm{mg} / \mathrm{dl}$ \\
GOT & $23 \mathrm{mU} / \mathrm{ml}$ & Antinuclear antibody $(-)$ \\
GPT & $9 \mathrm{mU} / \mathrm{ml}$ & Anti-DNA antibody & $(-)$ \\
LDH & $355 \mathrm{mU} / \mathrm{ml}$ & P-ANCA & $(-)$ \\
BUN & $11.2 \mathrm{mg} / \mathrm{dl}$ & C-ANCA & $(-)$ \\
Cr & $0.4 \mathrm{mg} / \mathrm{dl}$ & PT & $11.8 \mathrm{sec} . \quad(81.4 \%)$ \\
Electrolytes & normal & APTT & $27.3 \mathrm{sec}$. \\
Amylase & $132 \mathrm{mU} / \mathrm{ml}$ & Fibrinogen & $22.3 \mathrm{mg} / \mathrm{dl}$ \\
CRP & $1.6 \mathrm{mg} / \mathrm{dl}$ & FDP & $10 \mu \mathrm{g} / \mathrm{ml}>$ \\
ASO & $0.55 \mathrm{IU} / \mathrm{ml}>$ & Factor XIl acitivty & $>90 \%$ \\
\hline
\end{tabular}

液化学検査では, 第 13 因子活性を含め著変なく ASO も陰性であった (Table 1)，当科での便培養 では Salmonella Enteritidis が検出された。本症例 の経過は良好で，腹部症状，関節症状，皮膚症状 も短期間で改善した (Fig. 1). 初期の検尿は正常で あったが，11月 25 日から尿蛋白 $2+$, 尿中赤血球 数 10〜20/HPF など腎炎を合併した。このため, ジピリダモールで経過をみたが，6力月後には尿 所見は正常となり現在にいたっている．便培養で Salmonella Enteritidis は 12 月中旬に陰性化した。 また，母の便培養でも患児と同様に Salmonella Enteritidis が同定された.

症例 $2: 6$ 歳, 男児 (症例 1 の兄).

主訴：左膝関節腫脹, 紫斑.
現病歴：1997年 9 月 12 日から Salmonella O9 による腸炎を発症し，症例 1 とともに市内の救急 病院でホスホマイシンなどで加療を受けていた。

11 月 5 日に左膝関節痛および腫脹がみられ，そ の後紫斑が出現したためアレルギー性紫斑病と診 断され当科へ紹介された。当科外来で経過観察を していたが，11月 8 日に頭部に血管神経性浮腫も みられ，11月 9 日に肉眼的血尿と排尿痛がみられ たため入院となった.

現症および経過：入院時には，両側下肢の紫斑 と左頭部と両側足関節の局所性浮腫があった．右 下腹部にごく軽度の圧痛があったものの, 腹部症 状は明らかではなかった. サルモネラ腸炎以後, アレルギー性紫斑病発症の誘因となるものはみら 
Fig. 2 Clinical course of patient 2.

NPO : nothing per os, LRD : low residual diet

IVH : intravenous hyperalimentation

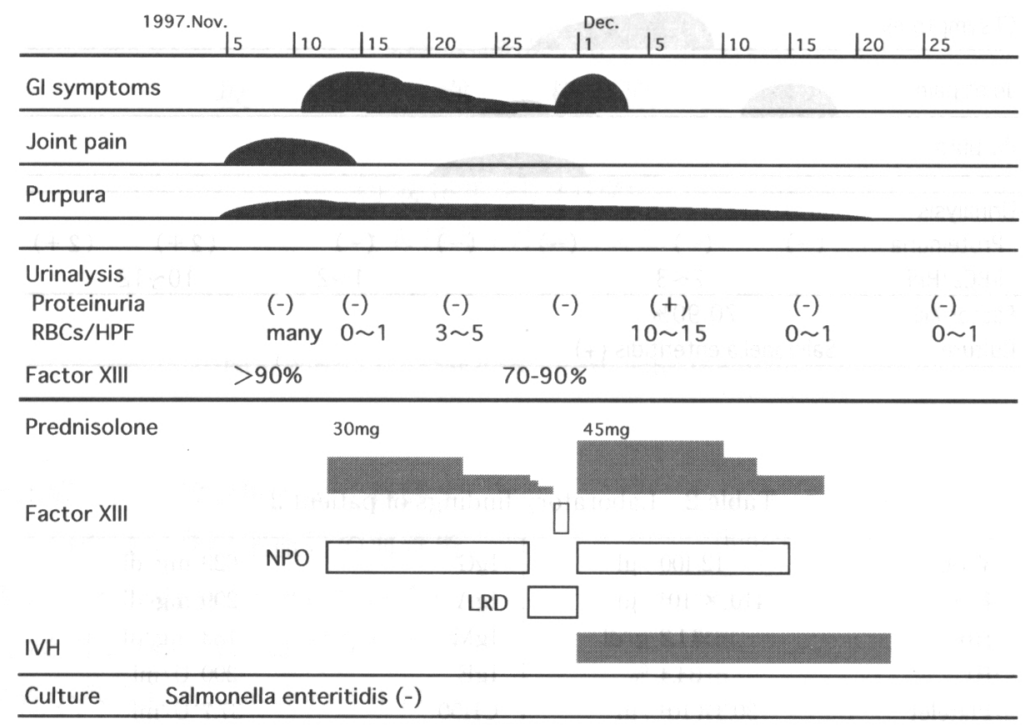

れなかった。

検查所見では血液一般, 生化学など異常なく第 13 因子も正常であった (Table 2) . 各種自己抗体 も陰性であり, ASO や咽頭培養でも溶連菌感染を 示唆する所見はなかった。排尿痛など膀胱炎を示 唆する症状があったが，尿中赤血球が多数みられ たものの白血球数は有意でなく尿培養も陰性で あった。このため, 細菌による膀胱炎は否定的で あり, 肉眼的血尿はアレルギー性紫斑病に合併し た出血性膀胱炎と考えられた。

本症例は，11月 12 日に腹痛が激しくなり，下 血, 嘔吐をともない経口摂取はまったく不可能と なった (Fig. 2). 腹部症状に対して絶飲食として, プレドニゾロン $30 \mathrm{mg} /$ 日 $(1.5 \mathrm{mg} / \mathrm{kg} /$ 日)の静注投 与を開始した. 腹部症状は次第に改善したため, 半消化態栄養剤（エンシュアリキッド）を開始し たところ,再び激しい腹痛および 1 日 10 回以上の 新鮮血の下血がみられるようになった.このため, 12 月 1 日から絶飲食としてプレドニゾロンを 45 $\mathrm{mg} /$ 日 $(2.2 \mathrm{mg} / \mathrm{kg} /$ 日) を再開, 同時に経静脈栄養 (IVH) を開始した。その後の経過はきわめて良好 となり，12月 4 日には腹部症状はほぼ消失した。
以後, プレドニゾロンの減量, 離脱をしたが, 再 度の悪化はなく改善した。本症例では， 12 月 22 日に蛋白尿 $1+$, 赤血球数 10 15 個/HPF が見ら れたが，以後の尿所見は正常であり，腎炎の合併 は明らかでなかった。当科での便培養は陰性で あったが, 腸炎は症例 1 と同様 Salmonella enteritidis によると考えられた。

\section{考案}

アレルギー性紫斑病は 3 12 歳の小児に好発 し, 日常比較的よく経験する疾患である. 発症機 序として感染, 薬剂, 食物, 寒冷などの誘因によ り何らかの IgA 抗体産生が立進し, IgA 免疫複合 体が小血管へ沈着するため血管炎を生じると推察 されている．本症に罹患した症例の血清中の vascular endothelial growth factor $の$ 増 加 ${ }^{3)}$, transforming growth factor $\beta$ 分泌 T 細胞の増加 ${ }^{4}$ な ど，断片的な免疫反応活性化が知られているもの の，その詳細はほとんど解明されていない。今回 の 2 症例は兄妹であったが, まれに家族内発症も みられる

症例 1 は Salmonella Enteritidis による腸炎後に アレルギー性紫斑病に罹患し, 症例 2 も同様と考 
えられる.アレルギー性紫斑病の誘因の中で因果 関係が報告されている感染症には $\mathrm{A}$ 群溶連菌, ブ ドウ球菌, カンピロバクター, レジオネラなどの 細菌の他, EB ウイルス, B 型肝炎ウイルス, 水痘, 麻疹, パルボウイルスなどのウイルス, また, マ イコプラズマ感染症の報告もある。一方，これら の感染症とアレルギー性紫斑病との因果関係は十 分に明らかでないという報告もある゙.

サルモネラ感染症に関連した報告はきわめて少 ないが, Fiocchi ら ${ }^{1)}$ は消化器症状と急性腎不全で 発症し, 腎生検でメサンギウムに IgA の沈着があ り, $25 \%$ の糸球体に半月体がみられ，便培養と血 液培養でS. hirschfeldii が検出されたアレルギー 性紫斑病の 19 歳男子例を報告している。また, Youmbissi ら ${ }^{21}$ は 50 歳の女性で, S. typhi 感染症に 合併した症例を報告している。我々の 2 症例も， アレルギー性紫斑病と関連した他の誘因がみられ なかったことから, S. enteritidis 腸炎に関連した可 能性がある。

腸管粘膜においては, 細菌およびその菌体成分, 食物などの抗原刺激により，腸管上皮細胞，樹状 細胞, 腸管上皮細胞間, 粘膜固有層の免疫担当細 胞などにより免疫反応が惹起される。通常, 細菌 の場合には Th1 優位であり, サルモネラにより誘 導される腸管での免疫反応も $\mathrm{Th} 1$ 優位とされて いる. しかしながら, 腸管での免疫反応は Th1/Th 2 とその抑制性 $\mathrm{T}$ 細胞という単純な機序ではな く, サルモネラ菌は Th1 型免疫反応とともに高い $\operatorname{IgA}$ 応答も引き起こす ${ }^{7)}$. 今回のサルモネラ腸炎 に合併したアレルギー性紫斑病発症の機序として は，菌および菌由来の因子自体による腸管および
全身の免疫反応に関連した可能性がある.一方， サルモネラ腸炎による腸管の病変により食物抗原 に対する粘膜での免疫反応が惹起され，アレル ギー性紫斑病として発症したことも考えられる。

また，腸炎に対して投与された薬物によることも 否定できない. 今回の 2 症例のアレルギー性紫斑 病とサルモネラ感染症との関連を示す確実なエビ デンスはないが, 今後, 症例報告の集積により因 果関係および発症機序の解明が必要である.

\section{文献}

1) Fiocchi O, Stabellini G, Squerzanti $R$, Stabellini $N$, Bedani PL, Tataranni G, et al. : Henoch-Schönlein purpura after Salmonella hirschfeldii infection. Nephron $1990:$ p.316-20.

2) Youmbissi TJ, Malik T, Ajit Kumar S, Rafi A, Al Khursanny AI, Karkar A : Henoch-Schönlein nephritis and salmonella typhi septicaemia. Nephrol Dial Transplant $2001 ; 16: 1081-2$.

3) Topaloglu R, Sungur A, Baskin E, Besbas N, Saatci U, Bakkaloglu A : Vascular endothelial growth factor in Henoch-Schonlein purpura. J Rheumatol $2001 ; 28: 2269-73$.

4) Yang YH, Huang MT, Lin SC, Lin YT, Tsai MJ, Chiang BL : Increased transforming growth factor-beta (TGF-beta) -secreting $\mathrm{T}$ cells and IgA anti-cardiolipin antibody levels during acute stage of childhood Henoch-Schonlein purpura. Clin Exp Immunol 2000; $122: 285-90$.

5) Levy-Khademi F, Korman SH, Amitai Y : Henoch-Schönlein purpura : Simultaneous occurrence in two siblings. Pediatr Dermatol 2000 ; $17: 139-40$.

6) Saulsbury FT : Epidemiology of Henoch-Schönlein purpura. Cleve Clin J Med 2000 ; 69 Suppl $2:$ SII87-9.

7）土肥多恵子：Th1/Th2 型粘膜免疫応答と消化管 炎症. 医学のあゆみ $2001 ; 199: 75-8$. 
Two Siblings with Allergic Purpura Following Salmonella O9 Enterocolitis

Takashi SAKANO \& Keita MATSUBARA

Department of Pediatrics Hiroshima Prefectural Hospital

Two siblings with allergic purpura after Salmonella O9 infection were reported. A girl (patient 1) aged 4 years and 4 months started to have knee joint pain and abdominal pain followed by purpura of the lower extremities and was referred to us for treatment of allergic purpura. She had contracted enterocolitis one month before visiting our hospital and Salmonella enteritidis was identified. During the course of the illness she had nephritis associated with allergic purpura. However, she made a favorable progress and proteinuria and hematuria disappeared within 6 months. A boy (an elder brother of patient 1) aged 6 years was admitted to our hospital because of the allergic purpura. He similarly had contracted Salmonella enterocolitis. He had severe gastro-intestinal symptoms including abdominal pain, vomiting and bloody stool, which rapidly subsided after initiation of treatment with intravenous hyperalimentation combined with prednisolone. It is possible that allergic purpura in our patients was closely associated with Salmonella enteritidis infection. Further accumulation of cases is a requisite to clarify an association of Salmonella enteritidis infection with allergic purpura and pathogenesis of allergic purpura.

[J.J.A. Inf. D. 77 : 986 990, 2003] 